\title{
Intellectual Property in the Context of Global Ethics
}

\section{Cristina LAZARIUC*, Ecaterina LOZOVANU ${ }^{*}$}

\begin{abstract}
Today we are the subjects and witnesses of the continuous development and transformation of society, which has made rapid leaps from modern to the informational and knowledge-based society. In this sense, in order to ensure technological, economic and social progress, Intellectual Property Rights (IPR) must become the only key element for protecting ideas, stimulating innovation and creativity, designing and contributing to the creation of technology. In this article the authors emphasize the need to address IPR in the context of global ethics, because IPR is also the social responsibility and moral duty of every global citizen, whether creative or consumer, to respect the cultural and intellectual heritage of humanity and to contribute to its diversification and to overcome the challenges of the contemporary world in the digital age. In the current context of the globalization of economic, social and even spiritual life, the need for morality of people is becoming more and more pressing, on which we will continue to focus our concerns, because any new issue addressed includes a component of global ethics.
\end{abstract}

Keywords: copy right, related rights, industrial property, global society, social responsibility, sustainable development.

JEL Code: A13, I23, I28, I31

\section{Introduction}

The approach of globalization, as a process of communion, cooperation and awareness of the fact that people, living in concrete societies and

${ }^{*}$ Cristina LAZARIUC is university lecturer at Technical University of Moldova, Chișinău, Moldova. E-mail: cristina.lazariuc@ssu.utm.md

${ }^{\dagger}$ Ecaterina LOZOVANU is associate professor at Technical University of Moldova, Chişinău, Moldova. E-mail: ecaterina.lozovanu@ssu.utm.md 
belonging to local civilizations, also belong to a "world community", has in itself a decisive legitimacy in the development of global society. In the current context of the globalization of economic, social and even spiritual life, the need for morality of people is becoming more and more pressing, on which it is necessary to focus our concerns. Dalai Lama believes that "In the age of globalization, the time has come to recognize that our lives are closely interconnected and to accept the global dimension of our behavior" (Dalai Lama, 2017, p. 45), which highlights that our interests are better defended, when we serve the interests of the entire human community.

Given the fact that rapid economic progress and the expansion of technology on a global scale have led to the reaffirmation of ethical considerations, it has become imperatively necessary to establish new ethical relations at all levels of global society, ensuring common cooperation and well-being. For these reasons, we believe that as relationships between people become closer and closer, overcoming spatial barriers, ethics becomes an issue that can no longer and should not be ignored. As a result, the angle of approach to the ethical horizon needs to be extended from a local /national/regional/continental framework worldwide, in a process that involves reporting to a system of universal values, norms and ethical concepts that provide a new understanding of things from the perspective of responsibility, solidarity, rights and obligations. In this context, a new concept has been established that analyzes and seeks ethical solutions to the challenges of the contemporary world, called global ethics.

\section{Literature review}

From the point of view of content, ethics can be considered global when the justifications, values, principles and norms that it contains have a moral significance and global coverage. An example of global ethical content is the duty of mutual respect, regardless of the criteria of human differentiation (gender, age, race, religion, political affiliation, level of education, financial situation, social position, function, etc.). Equal respect for any human being can be reflected in the help given directly to one's neighbor, unconditionally and selflessly, in the same way, whether he is a friend, a relative or a stranger. 
Also, the duty of mutual respect presupposes both respect for private property in general and respect for intellectual property, whether individual or collective.

Intellectual property (IP) is defined in various regulations and legislation governing both national and international law. For example, World Intellectual Property Organization (WIPO) notes that intellectual property refers to creations of the mind, such as inventions; literary and artistic works; designs; symbols, names and images used in commerce (WIPO). Article 9 of the Constitution of the Republic of Moldova stipulates that property consists of material and intellectual values. In addition, the Law No. 114 of 03-072014 on the State Agency of Intellectual Property defines: intellectual property as a private property owned by individuals or legal entities with the right of possession, use and disposal. Intellectual property includes objects resulting from intellectual activity in the industrial, economic, commercial, scientific, informational, literary and/or artistic fields, as well as in other fields (Law No. 114 of 03.07.2014).

S. Lakshmana Prabu, T.N.K. Suriyaprakash and C. Dinesh Kumar define intellectual property rights as the rights given to any particular person/organization for their new creations based on their minds for a certain period of time with an exclusive right over the use of their creation (Prabu, Suriyaprakash \& Kumar, 2012). In other words, in a broad sense, intellectual property refers to all the rights associated with intellectual activity in the following areas: literary, artistic and scientific, economic, commercial and industrial. Unlike property in general, which relates to the possession of material goods, intellectual property has been enshrined as an objective reality, referring to "spiritual goods." So, traditionally, intellectual property is divided into two branches:

- Copyright and related rights - refers to the protection of works in the literary field (novels, poems, plays) artistic (films, musical works), scientific (monographs, research projects, scientific articles, etc.), artistic-architectural (paintings, photographs, sculptures, architectural design), computer programs (games, websites, etc.) - copyright - as well as the results of the work of performers, producers of phonograms, video grams and broadcasting organizations, or by cable - related rights. In other words, this branch of 
intellectual property refers to categories of intellectual creation whose protection arises by itself, from the moment of their realization without the need for an examination and certification procedure. It is protected by copyright, provided that the creation is original.

- industrial property - refers to categories of industrially reproducible intellectual property in the form of products, processes or methods, including the protection of inventions, plant varieties, integrated circuit topographies, industrial designs, trademarks of products and / or services, designations of origin and traditional specialties guaranteed, etc. This type of property is protected on request, by certification, patent, based on an assessment of an official specialized body.

\section{Addressing the protection of intellectual property as an individual and global right and responsibility}

Intellectual property has become the subject of legislative regulations, which pursue two well-defined purposes. On the one hand, the legislation establishes the moral and economic rights of creators over their creations, as well as the rights of the public (beneficiaries, users) to have access to these creations. On the other hand, legal rules aim to promote creativity, spread and encourage a fair use of the results of this activity.

At the same time, in the information society and, more recently, in the knowledge-based one, the moral norms in force refer, including, to intellectual property and copyright, protecting them, and their violation is blamed, whether it is voluntary or involuntary. As a result, within the organizations, institutions (especially those whose activity has as purpose various types of creation) that operate locally, nationally, regionally, but also globally, codes of ethics and standards of good practice have been developed and adopted which expressly stipulate the obligation of each employee to respect the copyright and intellectual property of both his colleagues and creators outside the organization.

For example, universities around the world value these rights as essential to the institution's prestige and performance, to the reputation of its members, and to the effective conduct of academic life. The activity of 
universities, especially those with a technical profile, have as central objective not only the development of the instructive-educational process (teachinglearning-evaluation), but also the scientific research, as a result of which a diverse volume of intellectual creation is generated that is regulated by both branches of intellectual property: copyright and related rights, and industrial property. In turn, scientific research and technological development are the main creative and generating activities of economic and social progress. In this sense, universities, especially those with a technical profile, deal with: 1 . fundamental research, which includes the activity carried out in order to acquire new knowledge on phenomena and processes, as well as in order to formulate and verify hypotheses, conceptual models and theories; 2. applied research - an activity aimed mainly at using scientific knowledge to improve or develop new products, technologies and services, and, last but not least, 3.technological development - consisting of systems, engineering and technological engineering, through which the application and transfer of research results to economic agents is carried out, as well as the introduction and materialization of new technologies in the social field.

For these reasons, universities adhere unconditionally to the principles of full respect for intellectual property and ensuring academic integrity, and the promotion of these principles has become a criterion of performance and a central principle of their own activity and their institutional development policy. At the same time, it is obvious that respecting intellectual property and copyright is not only the social responsibility of the university, but also the professional obligation and moral duty of each member of the academic community, whether student, trainer, teacher or researcher. Following the analysis of the multiple situations of infringement of the right to intellectual property, detected in various academic and scientific communities, it was found that most frequently, infringement of intellectual property and moral rights of authors materializes by: - copying or paraphrasing a pre-existing text without mentioning the author: unassigned citation of ideas, arguments, data, results, etc. in a way that gives the impression that they belong to the person quoting - public presentation of ideas, research results, representations (visual, auditory) hypotheses, data, formulas, algorithms, program sequences, demonstrations, etc. of other authors as their own - the acquisition of 
intellectual contributions (translations, systematizations, etc.) of other authors and their public presentation without explicit mention of the sources of these contributions. All these are committed voluntarily or involuntarily, despite the fact that the academic norms in force expressly provide for the obligation to specify the sources.

The concerns about intellectual property are based on a series of unanimously recognized ethical principles: individual responsibility, autonomy from moral to legal evaluation, differentiation of responsibility and proportionality of sanctions according to the seriousness of the violation, impartiality and academic integrity. In this sense, the violation of this obligation is a serious fault and it must be severely sanctioned, with punishments that can go as far as expulsion, dismissal, interruption of collaboration, payment of material and moral damages, etc. Like all citizens, members of the academic community are liable to justice for any act contrary to the legal provisions regarding the enforcement of intellectual property. However, before having this legal responsibility, they have, first of all, a moral responsibility for its observance, which, if it is conscious, will not appeal to the coercive instruments of the former.

Another facet of individual responsibility is the obligation of each member of the academic community to show intransigence towards conduct or practices that infringe copyright, i.e. to adopt an attitude that does not allow compromises or conciliations or exceptions to the cause or to apply the principle of zero tolerance. Infringement of intellectual property is not a simple personal matter. It does not only affect the guilty party (taking into account the existence or the lack of guilty intent) and / or the injured party (taking into account the purpose and results of the acts committed, whose severity increases with the importance of their consequences - for example, obtaining academic positions, distinctions or awards, or benefits (titles, academic qualities, etc.)), but it is a matter of public morality and institutional performance. Governing bodies, teams, teachers and students have a moral and professional obligation to detect possible reprehensible acts, copyright infringement and to take action against them in order to protect a defining quality of university activity: academic integrity. Moreover, in the conditions of the information society and the knowledge-based one, in the conditions in 
which digital technologies have profoundly changed the way creative content is produced, distributed and accessed and in the context of a dynamic information environment, but prone to large-scale cyber-attacks, intellectual property protection goes beyond the national framework of legal and moral regulation, becoming the subject of international law and global ethics.

In this sense, intellectual property protection is an important component of national economic policies. Governments face complex choices on how to design an IP system that best serves their policy objectives, and how to respond to changes in technology and in business models that challenge the status quo. According to Ganguli P., recent exploration of the technology towards new dimension and path, IPR system helps to ensure and encourage new innovation and sharing the acquired knowledge during the innovation globally. Various IPR issues are:

- Domain names and trademarks: Copyright in cyberspace;

- Rights on traditional knowledge, prior art, material transfer agreement and bio-prospecting;

- Software and patents;

- Biotechnological inventions and moral issues and patents;

- Compulsory licensing options, border measures and parallel imports and exhaustion of IPR;

- Government control on export of technology (Ganguli P., 2000).

Although governed by various national laws, intellectual property rights (IPR) are also covered by European Union legislation. Article 118 of the Treaty on the Functioning of the European Union provides that, in the context of the establishment and functioning of the internal market, the Parliament and the Council establish measures for the creation of EU intellectual property law in order to ensure uniform IPR protection and to set up centralized authorization, coordination and control throughout the EU. For example, the European Union Intellectual Property Office (EUIPO) is responsible for managing the EU trademark and designs. Also, the EU Parliament is working to harmonize IPR by creating a single European system, in parallel with the national ones, for example: the EU trade mark and designs and the European unitary patent. All these measures provide the necessary regulatory framework for intellectual property to create added 
value for European businesses and economies, and as a result to contribute to the development and innovation of European society.

In addition, globally, in 1967, it was created the World Intellectual Property Organization (WIPO) which currently has 193 member states, including the Republic of Moldova, since 1991. The major goal stated by WIPO is to encourage creative work and the promotion of intellectual property anywhere in the world, so that the creativity of inventors and authors is recognized and rewarded. At this level, the international protection of IPR is an impetus for human creativity, with the effect of continuously expanding the field of science and technology and diversifying the world of literature and the arts. In addition, ensuring IPR protection globally would pave the way for international trade, ensuring a stable and conducive environment for the marketing of intellectual property products. In close cooperation with Member States and other stakeholders, WIPO is working to ensure the existence of an intellectual property system that remains a flexible and adaptable tool for prosperity and well-being, designed to enable the full exploitation of the potential of intellectual property in the benefit of current and future generations.

As a specialized agency of the United Nations, the World Intellectual Property Organization contributes to the Sustainable Development Goals by providing concrete services to its member states, enabling them to use the intellectual property system to drive the innovation, competitiveness and creativity needed to achieve these goals. The 2030 Agenda for Sustainable Development and its 17 Sustainable Development Goals (SDGs), adopted by all United Nations Member States in 2015, as the most ambitious development agenda in human history, is a roadmap to end poverty, protect the planet and ensure that all people live in peace and prosperity. In this regard, we emphasize that global society is not just about peace between nations. It embodies that special state of mind to which Spinoza referred: "Peace means more than the mere absence of war, peace is a virtue." $\mathrm{He}$ added: peace is "a state of mind, a disposition for goodwill, trust and justice."

Indeed, true peace exists only if people have the confidence and certainty that their interests are recognized and represented, are satisfied with their political system, and are guaranteed that their fundamental rights are 
respected. As a community of universal values, it represents this vision of freedom and justice, which places the individual and respect for human dignity in a central position and which cannot exist outside democracy (Tocqueville, 2017, p.23). Through constant dialogue and negotiations, applying the art of compromise and the ethical principles of human interaction, covering more and more issues and involving more and more countries, the promotion of world peace, as an indispensable condition for managing other global issues, is possible.

In this sense, in the context of global ethics, on the one hand, the human being must be considered the greatest value of the planetary society, whose dignity must be respected and promoted by creating the necessary conditions for the development of the human being as:

- free and multilaterally developed personality;

- specialist and professional with working conditions conducive to his continuous training;

- identity, not subject to the risk of depersonalization;

- citizen who actively participates in the social-political life at national and global level, in non-discriminatory conditions, of equity and equal opportunities;

- as a responsible person who contributes to the establishment of harmonious relations between man, nature and society, both locally and globally.

On the other hand, the human being must be considered the holder of global citizenship which involves the following responsibilities:

- to contribute to the common good and prosperity;

- to anticipate the impact of its actions on the security and well-being of others and on nature;

- to promote fairness and non-discriminatory treatment in relation to other people,

- to protect the interests of future generations by developing and preserving global assets;

- to respect the cultural and intellectual heritage of mankind and to contribute to its diversification; 
- to be an active participant in the governance, promotion and implementation of social reforms and the solution of the problems of the global society.

All these situations and responsibilities cannot be ensured if the right to intellectual property has not been promoted and respected. At the same time, beyond legally recognized rights, there are inalienable moral rights, such as the rights of each author, that his results and contributions be respected, that his ideas and data not be taken over or exploited without the necessary recognition and that the fraudulent appropriation of intellectual contributions to be appropriately sanctioned. These rights are indispensable elements for stimulating creative activity and performance.

Thus, intellectual property is a critical incentive for innovation and creativity, which in turn are key to the success of the SDGs. Only through human ingenuity it will be possible to develop new solutions that: eradicate poverty; boost agricultural sustainability and ensure food security; fight disease; improve education; protect the environment and accelerate the transition to a low-carbon economy; increase productivity and boost business competitiveness. In turn, all these challenges of the contemporary world require ethical approaches at the global level.

WIPO seeks to contribute to a better understanding of the economic effects of different IP policy choices and to offer a first entry point for information on the economics of IP. Also, WIPO works globally, with its member states as well as public and private organizations, to help develop understanding of and respect for intellectual property. Building respect for IP means helping create an environment in which intellectual property can fulfill its role to stimulate innovation and creation. It also means fostering an environment in which the system of protection provides equitable benefits to both owners and users of IP. Building respect for IP requires integrating elements encompassing developments in legislation, awareness and cultural change, business and technology solutions, and institutional collaboration.

\section{Conclusions}

Therefore, at the individual level, on the one hand, for the creator, the protection of intellectual property rights represents the security of 
appreciation of creativity, originality and efforts made in the creative process. Given the lack of legal and moral rules that would protect intellectual property, an inventor would consider that his investment in developing a new idea or product could be neglected, which would diminish his motivation to create more innovative intellectual products in the future. On the other hand, for the beneficiary/consumer the protection of the intellectual property right represents the guarantee of the quality and the inoffensiveness of the purchased products/services. IPR guarantees consumers that the products they buy have been tested, approved and safe. A counterfeit product may look exactly like the original, but has often not been tested to make sure it is safe. This is especially true for fake cosmetics and consumables.

Also, intellectual property allows consumers to make choices between competing entrepreneurs, and the goods and services they sell. Therefore, IP is inherently pro-competitive as it ensures the protection of differentiated, intangible business assets. Without IP, less efficient manufacturers and service providers would try to lure clients by copying the goods and services of more efficient competitors. The latter would lose any incentive to improve or to offer new products and services. Society as a whole would lose. But IP only performs that crucial role of ensuring competition when it protects genuine differences.

At the national level, infringements of intellectual property rights also deprive governments of tax revenue. This means a higher tax burden for businesses and individuals, who comply with the law and often means less money for schools, healthcare and social protection. At the global level, the protection of intellectual property rights is an essential parameter of progress in the field of research, innovation and employment, being at the same time the social and moral responsibility of every citizen. From this, we conclude that through the global dimension to which it aspires, ethics is more concerned with communities than individuals, its effectiveness being amplified, and the principles, norms and values of global ethics are applied in a context of global interconnection, which transcends national and continental spaces. In other words, global ethics does not simply internationalize a set of principles, but offers a new perspective for identifying alternative solutions 
to new global ethical dilemmas and challenges, starting from a common ground.

\section{References}

Convention Establishing the World Intellectual Property Organization. Retrieved from https://www.wipo.int/treaties/en/text.jsp? file_id $=283854$

Cyber Security Guide. October 2019. Retrieved from https://stisc.gov.md/sites/default/files/ghiduri/ghidul_securitatii_ciber netice_0.pdf

Dalai Lama. (2017). Dincolo de religie. Etică pentru o lume mai bună. Lifestyle Publishing.

Ganguli, P. (2000). Intellectual Priperty Rights. Imperatives for knoeledge industry. World Patent Information. p.61-62.

Lakshmana Prabu, S, Suriyaprakash, T.N.K, Dinesh Kumar, C. (2012). Intellectual Property Rights and its development in India. Pharma Times. 44(7): p.19-22

Law No. 114 of 03.07.2014 on the State Agency for Intellectual Property. Retrieved from https://www.legis.md/cautare/getResults?doc_id=110504\&lang=ro

Law No. 38 of 29.02 .2008 on trademark protection. Retrieved from https://www.legis.md/cautare/getResults?doc_id=93464\&lang=ro

Sustainable Development Goals of the 2030 Agenda for Sustainable Development $(U N)$, retrieved from https://sdgs.un.org/goals

Tocqueville, A. (2017). Despre democrație in America. București: Humanitas, p.43.

WIPO (2004). Handbook on Intellectual Property. Retrieved from https://www.wipo.int/edocs/pubdocs/en/wipo_pub_489.pdf 